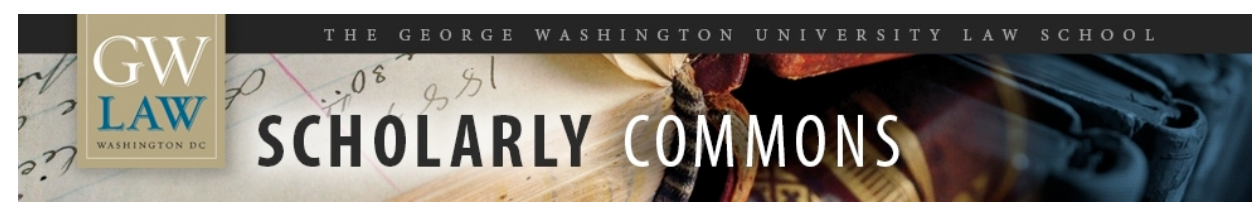

\title{
One Person's Statement to Prove Another's Actions
}

Stephen A. Saltzburg

George Washington University Law School, ssaltz@law.gwu.edu

Follow this and additional works at: https://scholarship.law.gwu.edu/faculty_publications

Part of the Law Commons

\section{Recommended Citation}

Saltzburg, Stephen A., One Person's Statement to Prove Another's Actions (2012). 27 Crim. Just. (2012); GWU Law School Public Law Research Paper No. 2012-153; GWU Legal Studies Research Paper No. 2012-153. Available at SSRN: http://ssrn.com/abstract=2669931

This Article is brought to you for free and open access by the Faculty Scholarship at Scholarly Commons. It has been accepted for inclusion in GW Law Faculty Publications \& Other Works by an authorized administrator of Scholarly Commons. For more information, please contact spagel@law.gwu.edu. 


\section{One Person's Statement to Prove Another's Actions BY STEPHEN A. SALTZBURG}

I t has been long established-since Mutual Life Insurance Co. v. Hillmon, 145 U.S. 285 (1892) - that statements of an individual's present intention to do a future act may be admitted to prove that the individual did in fact do the act. Dictum in Hillmon stated that one person's statement of a present intent to do a future act with another person could be used to prove that the declarant did the intended act and did it with the other person mentioned in the statement. When Congress enacted the Federal Rules of Evidence into law in 1975, a House of Representatives committee report indicated a desire to limit the use of a hearsay statement of a present intent to do a future act to prove the declarant's actions, not those of a third person. The Senate report was silent on the matter, and whether the Hillmon dictum remained good law was not resolved as the Federal Rules were enacted into law.

The hearsay issue of whether to limit use of a declarant's statement of an intention to do a future act to prove the declarant's actions alone or also the actions of another person remains alive in both federal and state courts. Resolution of the hearsay issue is more important today than some years ago since the United States Supreme Court held that the Sixth Amendment Confrontation Clause extends only to testimonial statements. (Crawford v. Washington, 541 U.S. 36 (2004).) Since few statements of a present intent to do a future act are testimonial, the only protection for a defendant in a criminal case from having a declarant's statements used to prove the defendant's actions is the hearsay rule.

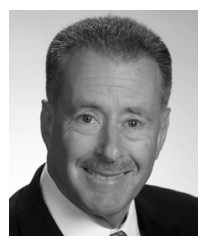

STEPHEN A. SALTZBURG, a past chair of the Criminal Justice Section, is the Wallace and Beverley Woodbury University Professor at George Washington University School of Law in Washington, D.C., and contributing editor to Criminal Justice magazine. He is also author of the book, Trial Tactics, Second Edition (American Bar Association 2009), an updated and expanded compilation of his columns.
State v. McLaughlin: An Illustrative Case The importance of the hearsay rule to resolution of this issue is well illustrated by State v. McLaughlin, 14 A.3d 720 (N.J. 2011). The case arose as a result of an alleged plan by the defendant, Eduardo McLaughlin, his brother Pablo, and a friend named Miguel Serrano to rob a grade-school friend of the defendant, Thong Ming Hyunh. Hyunh was employed in a check cashing business that often transported large sums of cash. The defendant, along with the others, arranged for the defendant to ride with Hyunh in Hyunh's sister's van after he picked up approximately $\$ 17,000$ in cash. The two drove to where Pablo lived with his girlfriend. When they arrived, Pablo and Serrano were already there. A struggle ensued while the money was counted, and the defendant and Serrano killed Hyunh and divided the money. The two bought an all-terrain vehicle and drove the van to a secluded location where they set it on fire before dumping Hyunh's body.

The police responded to the van fire and traced the van to the victim's sister, who reported her brother missing the following day. As a result of discovering that the defendant and Hyunh had several telephone conversations immediately before Hyunh disappeared, the police interviewed the defendant. The defendant said that he and Hyunh had planned to go out for drinks, but Hyunh had not called back.

The investigation led the police to Serrano. They searched Serrano's home and recovered a large sum of cash along with a bracelet identified as belonging to Hyunh. Serrano's girlfriend, Jessica Pabón, told the police that she had seen the defendant wearing that bracelet. More cash was discovered at the home of Serrano's mother.

Eduardo McLaughlin was tried alone for firstdegree murder, first-degree felony murder, and other crimes. The jury convicted the defendant of aggravated manslaughter (as a lesser included offense of murder), felony murder, robbery, hindering apprehension, and conspiracy.

\section{The Evidence Issue}

The prosecution called Jessica Pabón as a witness and asked her whether Serrano had told her if he was planning the robbery with someone else. Defense counsel objected, the trial judge overruled the objection, and Pabón testified that Serrano said that he was planning the robbery with "Eddie," the defendant, and that he and the defendant

Published in Criminal Justice, Volume 27, Number 1, Spring 2012. (c) 2012 by the American Bar Association. Reproduced with permission. All rights reserved. This information or any portion thereof may not be copied or disseminated in any form or by any means or stored in an electronic database or retrieval system without the express written consent of the American Bar Association. 
were going to watch the victim to see what he "did throughout the day, something like that." The trial court admitted the testimony as a coconspirator declaration. On appeal, the Appellate Division of the New Jersey Superior Court held that the coconspirator exception was inapplicable because the statements were not made in furtherance of the planned robbery. That court determined, however, that the statements were admissible under the "state of mind" exception, New Jersey Rule of Evidence 803(c)(3). The New Jersey exception is virtually the same as Federal Rule of Evidence 803(3) and creates a hearsay exception not conditioned on unavailability for a "statement made in good faith of the declarant's then existing state of mind, emotion, sensation or physical condition (such as intent, plan, motive, design, mental feeling, pain, or bodily health), but not including a statement of memory or belief to prove the fact remembered or believed."

The New Jersey Supreme Court granted the defendant's petition for certification to review whether Serrano's hearsay statements, as testified to by Jessica Pabón, were admissible under New Jersey Rule of Evidence 803(c)(3).

\section{The Available Approaches}

The New Jersey Supreme Court observed that the state had recognized a "state of mind" exception to the hearsay rule in Hunter v. State, 40 N.J.L. 495, 541 (E. \& A. 1878), 14 years before Hillmon, and Hillmon actually cited Hunter. That is the exception codified as New Jersey Rule of Evidence 803(c)(3).

The court looked to what other United States courts had done when a declarant's statement of a present intent to do a future act with another person is offered against the other person and found three general approaches to the problem. Some courts narrowly apply Hillmon so that a declarant's statement may only be admitted to prove the declarant's subsequent conduct. Other courts take a more expansive approach and uniformly allow admission of the statement to prove the subsequent conduct of both the declarant and nondeclarant in all instances. Still other courts allow admission of the statement as proof of the subsequent conduct of the nondeclarant if there is independent evidence to corroborate the hearsay statement as to the nondeclarant.

\section{The Holding}

The court reversed the defendant's convictions and held that: [t]he 'state of mind' hearsay exception should be construed narrowly, focusing specifically on the declarant's state of mind and whether that state of mind is directly relevant to the issues at trial. Because the state of mind of the declarant of the hearsay offered here was not directly relevant to the prosecution of defendant and the hearsay statement itself, without redaction, imputed to defendant the intent to commit a crime, its admission was error. (McLaughlin, 14 A.3d at 189.)

\section{The Reasoning}

The court emphasized that the first step in determining admissibility of a declarant's statement is deciding whether it is relevant. In the instant case, the court concluded that Serrano's statement was irrelevant because his state of mind was not at issue in the case. This, by itself, would have been sufficient to warrant reversal, but the court indicated a desire to provide clarity for future cases.

Thus, it went on to hold that, even if relevant, a declarant's statement of a present intention to do a future act must be redacted if it refers to another person against whom the statement is offered. The court reasoned as follows:

This must be so because, as State v. Roach, 146 N.J. 208, 224, 680 A.2d 634, cert. denied, 519 U.S. 1021, 117 S. Ct. 540, 136 L. Ed. 2d 424 (1996), explains, "[i]t is well-settled that the admission of the statement of a co-defendant at a joint trial that implicates defendant without the right of cross-examination constitutes prejudicial error." (citing Bruton v. United States, 391 U.S. 123, 88 S. Ct. 1620, 20 L. Ed. 2d 476 (1968); State v. Young, 46 N.J. 152, 215 A.2d 352 (1965)). . . . If a hearsay declarant unavailable for crossexamination directly implicates a defendant, the principles that inform Bruton and Roach also guide the redaction process to be followed in the context of a state of mind hearsay statement that identifies a non-declarant defendant. As this Court has noted, "limiting instructions [to the jury] are, as a matter of constitutional law, insufficient to overcome the prejudice to a remaining defendant in a joint trial in which an unavailable codefendant inculpates the remaining defendant[.]" State v. Meléndez, 129 N.J. 48,

Published in Criminal Justice, Volume 27, Number 1, Spring 2012. (c) 2012 by the American Bar Association. Reproduced with permission. All rights reserved. This information or any portion thereof may not be copied or disseminated in any form or by any means or stored in an electronic database or retrieval system without the express written consent of the American Bar Association. 
57, 609 A.2d 1 (1992) (citing Bruton, supra, 391 U.S. at 124, 88 S. Ct. at 1621, 20 L. Ed. $2 \mathrm{~d}$ at 478). Therefore, the question becomes what - in order to insure fairness in the proceedings and stout fealty to the constitutional guarantee that a defendant is entitled to confront and cross-examine those who bear witness against him - must a court do in order to redact or "sanitize" a co-defendant's hearsay statement that implicates the non-testifying defendant?

(Id. at 733-34.)

The court's answer was as follows:

We therefore express what Meléndez, supra, 129 N.J. at 57-60, 609 A.2d 1, implies: a nontestifying declarant's state of mind hearsay statement concerning future acts by the nondeclarant/defendant properly must be redacted to omit references to the non-declarant/ defendant in order to satisfy both Evidence Rule 803(c)(3) as well as the requirements of the Confrontation Clause, U.S. Const. amend. VI, and its parallel in the New Jersey Constitution, N.J. Const. art. I, $\uparrow 10$.

(Id. at 735.)

\section{The Reasoning Applied}

The court applied its reasoning to the facts of the case as follows:

Had Serrano's hearsay statements been offered during Serrano's own trial, the statements would have been admissible as against him. See N.J.R.E. 803(b)(1) (excepting party's own statements from hearsay rule). However, in a trial where defendant stands alone, those same statements addressing Serrano's state of mind in respect of defendant's possible future acts are not relevant to a central issue in the determination of defendant's guilt. And, at their core, those hearsay statements are unreliable: Serrano's hearsay statements concerning defendant as offered through Jessica Pabón's testimony cannot be cross-examined, and the absence of an effective substitute for crossexamination fails to satisfy the "good faith" requirement of Evidence Rule 803(c)(3) and is fatal to their admissibility. Defendantwho made no statements of a presently ex- isting state of mind - cannot otherwise be liable vicariously for the statements made by Serrano in respect of Serrano's state of mind, particularly where, as here, there was no showing that defendant knew of or otherwise ratified Serrano's hearsay statements. As a result, the admission of those hearsay statements without redaction and over objection-thereby allowing the jury to infer that Serrano's hearsay statements proved that defendant acted as Serrano claimed to his girlfriend-constitutes reversible error that commands a retrial.

(Id. at 735-36.)

\section{The Reasoning Analyzed; Some Lessons}

1. The court was probably wrong in concluding that Serrano's statement of intent was irrelevant in the defendant's trial. Had Serrano testified and admitted participation, his statement might well have been irrelevant. But, assuming that he did not testify (and the court did not suggest he did), then the government was required to prove how the victim died, which meant it had to prove that Serrano was there with the defendant. Thus, Serrano's statement of a present intention to rob the victim was probative of the fact that he did actually participate in the robbery that led to murder. Even if the statement is redacted to remove any mention of the defendant, it is relevant to the prosecution's case.

2. The court's references to the US Supreme Court's opinion in Bruton as well as the New Jersey Supreme Court's own opinions in Roach, Young, and Meléndez fail to indicate that all of the opinions preceded the decision in Crawford. It is virtually certain that Serrano's statements to Jessica Pabón were not testimonial statements. Therefore, the Sixth Amendment confrontation clause is not applicable. Of course, the New Jersey Supreme Court may rely on the New Jersey Constitution to provide more confrontation rights than are guaranteed by the US Constitution. But, it is important for readers of the opinion to recognize that redaction is not required by the Sixth Amendment.

3. The fact that the Sixth Amendment confrontation clause does not apply drives home the point that the hearsay determination is critical. If Serrano's statements are not admissible under evidence rules such as New Jersey Rule of Evidence 803(c) (3) or Federal Rule of Evidence 803 (3), then redaction is not only appropriate, but required - not as a result of the application of the

Published in Criminal Justice, Volume 27, Number 1, Spring 2012. (c) 2012 by the American Bar Association. Reproduced with permission. All rights reserved. This information or any portion thereof may not be copied or disseminated in any form or by any means or stored in an electronic database or retrieval system without the express written consent of the American Bar Association. 
Sixth Amendment but as a fair application of the hearsay rule. After all, there is no way a limiting instruction would work in a case like the instant case, given the fact that there is a single defendant who is not the hearsay declarant.

4. Those state courts that admit statements like Serrano's - with or without corroborationto prove that he acted and did so along with defendant McLaughlin may continue to do so. Af- ter all, they have the authority to interpret their evidence rules as they see fit, and absent a state constitutional problem with admission of the evidence, the fact that it is nontestimonial means that federal law is irrelevant.

5. As for federal courts, they must rely on the law of the respective circuit until such time as the US Supreme Court decides to decide on the reach of Federal Rule of Evidence 803(3). 